\title{
THE RELATIVE EFFECTIVNESS OF STEADY STATE CARDIO AND HIGH INTENSITY INTERVAL TRAINING ON CARDIORESPIRATORY FITNESS AMONG STUDENTS AT SCHOOL OF HEALTH POLYTECHNICS, SURAKARTA
}

\author{
Mei Kusumaningtyas, Hana Kristina \\ School of Health Polytechnics, Surakarta
}

\begin{abstract}
Background: Cardiorespiratory fitness essential to prevent the risk cardiovascular disease. This study aimed to determine the relative effectiveness of Steady State Cardio (SSC) and HighIntensity Interval Training (HIIT) on cardiorespiratory fitness in the early adult age group.

Subjects and Method: This was a randomized control trial conducted at the School of Health Polytechnics, Surakarta, from October to November, 2019. A total sample 45 students was divided into 2 groups: (1) SSC group and (2) HIIT group. The dependent variable was cardiorespiratory fitness. The independent variables were SSC and HIIT. The measuring instrument was a multi-stage fitness involving a 20 meter long run. The results were converted into VO2max level. The data were analyzed by Mann Whitney.

Results: After the intervention, the VO2max level was higher in the HIIT group (Mean= 24.28; $\mathrm{SD}=5.42$ ) than the $\mathrm{SSC}$ group (Mean= 21.66; $\mathrm{SD}=6.99$ ), but it was statistically non-significant $(\mathrm{p}=0.503)$.

Conclusion: Steady State Cardio and High Intensity Interval Training have comparable effect on cardiorespiratory fitness.
\end{abstract}

Keywords: high intensity interval training, steady state cardio, cardiorespiratory fitness, VO2max

\section{Correspondence:}

Mei Kusumaningtyas. School of Health Polytechnics, Surakarta. Jl. Adi Sumarmo, Tohudan, Colomadu, Karanganyar, Indonesia. Email: meikusumaningtyas@gmail.com. Mobile: 085725646444 